УДК 342.951

DOI: https://doi.org/10.54929/pmtl-issue2-2021-05

\title{
ДЕЯКІ ОСОБЛИВОСТІ КЛАСИФІКАЦІЇ ЗДІЙСНЕННЯ АДМІНІСТРАТИВНИХ ПРОЦЕДУР У СФЕРІ ЗАХИСТУ ДОВКІЛЛЯ ТА ПРИРОДНИХ РЕСУРСІВ
}

\author{
SOME FEATURES OF CLASSIFICATION OF ADMINISTRATIVE \\ PROCEDURES IN THE FIELD OF ENVIRONMENTAL PROTECTION \\ AND NATURAL RESOURCES
}

\author{
Манько Г. В. \\ суддя Господарського суду Дніпропетровської області \\ ORCID: 0000-0003-3226-2200 \\ Hennadii Manko
Judge of the Commercial Court of Dnipropetrovsk region
}

Наукова стаття присвячена висвітленню критерії класифікації здійснення адміністративних процедур у сфрері захисту довкілля та природних ресурсів. На підставі визначених особливостей здійснення адміністративних процедур у сфрері захисту довкілля та природних ресурсів сорормульована авторська дефрініція досліджуваної суспільно-правової категорії. Проведено класифікацію здійснення адміністративних процедур у сфрері захисту довкілля та природних ресурсів за такими критеріями, як: правові наслідки їх надання, суб’єкт-споживач, вид прийнятого адміністративного акту, зміст та обсяг процедурних дій. Виявлено у сфері охорони навколишнього природного середовища та природних ресурсів поділ послуг з видачі за типом прийнятого адміністративного акта адміністративні процедури на: а) процедури атестації; б) порядок отримання довідки; в) дозвільні процедури; г) процедури ліцензування; д) процедури отримання рішення на продаж земельної ділянки комунальної власності; отримання відводу; е) порядок отримання експертного висновку (у разі надання негативного висновку). Ключові слова: адміністративні процедури у сфері захисту довкілля та природних ресурсів, довкілля, екологія, класифікація, особливості, природні ресурси.

Научная статья посвящена освещению критериев классификации осуществления административных процедур в сорере защиты окружающей среды и природных ресурсов. На основании определенных особенностей осуществления административных процедур в сфрере защиты окружающей среды и природных ресурсов, сформулирована авторская дефиниция исследуемой общественно- правовой категории. Проведена классификация осуществления административных процедур в сфрере защиты окружающей среды и природных ресурсов по таким критериям, как: правовые последствия их предоставления, субъект- потребитель, вид принятого административного акта, содержание и объем процедурных действий. Выявлено в сфрере охраны окружающей природной среды и природных ресурсов разделение услуг по типу выдачи принятого административного акта административных процедур на: а) процедуры аттестации; б) порядок получения справки; в) разрешительные процедуры; г) процедуры лицензирования; д) процедуры получения решения на продажу земельного участка коммунальной собственности; получение отвода; е) порядок получения экспертного заключения (при предоставлении отрицательного заключения). Ключевые слова: административные процедуры в области защиты окружающей среды и природных ресурсов, окружающей среды, экология, классификация, особенности, природные ресурсы.

The scientific article is devoted to highlighting the criteria for classifying the implementation of administrative procedures in the field of environmental protection and natural resources. On the basis of certain features of the implementation of administrative procedures in the field of environmental protection and natural resources, the author's definition of the studied social and legal category is formulated. The classification of administrative procedures in the field of environmental protection and natural resources according to such criteria as: the legal consequences of their provision, the consumer, the type of administrative act, the content and scope of procedural actions. According to the type of adopted administrative act, administrative procedures in the field of environmental protection and natural resources are divided into issuance services: a) certification procedures (for example, issuance of a hunter's certificate or its duplicate, etc.); b) procedures for obtaining a certificate (providing information from the State Land Cadastre in the form of an extract from the State Land Cadastre of land within the territories of administrative-territorial units; providing a certificate from the state statistical reporting on land availability and distribution by landowners, land users, lands (according to the form 6-land)); c) permitting procedures (in the presence of a pension certificate of the subject of the application for the service specified in the previous paragraph; granting permission to terminate the right to child support in connection with the acquisition of ownership of real estate); d) licensing procedures (issuance of a license for storage of natural gas, gas (methane) of coal deposits in excess of the level established by the license conditions or its re-issuance; issuance of a license to conduct business activities for the production of industrial explosives); e) procedures for obtaining a decision (issuance of decisions of the 
city council on land plots of communal property, in case of termination of the land lease agreement or termination of the right of permanent use; issuance of a decision of the city council on consent to sale of land plot of communal property); k) procedures for obtaining a diversion (granting a mining allotment for the development of mineral deposits of national importance, construction and operation of underground structures and other purposes not related to the extraction of minerals; registration of mining allotments provided for the development of local mineral deposits); f) procedures for obtaining an expert opinion (conducting mandatory, voluntary state examination of land management documentation, as well as selective state examination of land management documentation) (in case of issuing a negative opinion). Key words: administrative procedures in the field of protection of environment and natural resources, environment, ecology, classification, features, natural resources.

Постановка проблеми. Прийняття Закону України «Про адміністративні послуги» стало одним з досягнень проголошеної Концепції адміністративної реформи 1998 року. Визначення концепції «служіння» в системі публічно-владних відносин вимагає переосмислення особливостей адміністрування у всіх сфрерах суспільного життя. На жаль, в межах національного правового поля не визначено сутність здійснення адміністративних процедур у сфрері захисту довкілля та природних ресурсів, не сформульовано критерії їх класифікації, але правозастосовча практика свідчить про використання такого терміну.

Аналіз останніх досліджень і публікацій. Окремі аспекти проблеми дослідження понятійного апарату здійснення адміністративних процедур в цілому розглядали В. Б. Авер'янов, К. К. Афанасьєв, В.М.Бевзенко, Ю. П. Битяк, І. В. Дроздова, В. М. Гаращук, І. П. Голосніченко, С.В.Ківалов, І. Б. Коліушко, Т. О. Коломоєць, В. К. Колпаков, А. Т. Комзюк, О. В. Кузьменко, А. С. Лагода, Є. О. Легеза, П. С. Лютіков, Р. С. Мельник, Г.М. Писаренко, В. П. Тимощук тощо.

Виділення невирішених раніше частин загальної проблеми, котрим присвячується означена стаття. Комплексне дослідження критеріїв здійснення адміністративних процедур у соері захисту довкілля та природних ресурсів не проводилось, що обумовило актуальність проведення даного дослідження та стало відправною метою цієї наукової статті.

Формулювання цілей статті (постановка завдання). Метою статті $€$ висвітлення критерієв класифікації здійснення адміністративних процедур у сфрері захисту довкілля та природних ресурсів.

Виклад основного матеріалу дослідження. Найбільш вживаним серед науковців визнається критерій класифрікацій адміністративних процедур у сфері міграції за галузями законодавства. Так, В.П. Тимощуком такий підхід до класифікації обумовлюється, тим, що земельні, господарські, соціальні відносини належать до галузей законодавства, які, так би мовити, «виросли» 3 адміністративного права і мають адміністративний характер.

Вчений В. С. Долечек виділяє критерії класифрікації адміністративних процедур - за предметом (характером) питань, за розв'язанням яких звер- таються особи до адміністративних органів [1]. За зазначеними критеріями можна виділити підприємницькі або господарські (реєстрація особи як суб'єкта підприємницької діяльності), соціальні (призначення державної соціальної допомоги), земельні (прийняття органом місцевого самоврядування рішення про надання земельної ділянки у користування), будівельно-комунальні та інші види адміністративних процедур [1].

Не менш важливим критерієм класифікації адміністративних процедур слід вважати рівень правового регулювання процедури їх надання [2, C. 457], або рівень встановлення повноважень щодо адміністративних процедур. За останнім критерієм відокремлюються адміністративні процедури з централізованим регулюванням (закони, акти Президента, Кабінету Міністрів); адміністративні процедури з локальним регулюванням (насамперед, акти органів місцевого самоврядування); адміністративні процедури зі «змішаним» регулюванням (коли має місце одночасно і централізоване, і локальне регулювання). Така класифікація, на думку В. П. Тимощука, дозволяє виробити певні правила щодо впорядкування системи адміністративних процедур, особливо адміністративних процедур з локальним регулюванням, оскільки саме цей вид послуг запроваджуються за ініціативою органів місцевого самоврядуванням без врахування об'єктивних можливостей їх здійснення [3, C. 125].

Серед особливостей здійснення адміністративних процедур у сорері захисту довкілля та природних ресурсів виділимо те, що такі послуги надаються державою в особі уповноважених органів. Також серед особливостей здійснення адміністративних процедур у сфері захисту довкілля та природних ресурсів $€$ специфічне коло споживачів таких послуг. Як правило, суб'єктами звернення за отриманням здійснення адміністративних процедур у сфері захисту довкілля та природних ресурсів $є$ такі особи, які $є$ за своєю сутністю є природокористувачами, тобто особами, які на законних підставах володіють природним ресурсом. Наприклад, споживачем здійснення адміністративних процедур у сфрері захисту довкілля та природних ресурсів з видачі ліцензії на видобування дорогоцінних металів і дорогоцінного каміння, дорогоцінного каміння органогенного утворення, напівдорогоцінного каміння є суб'єкт 
господарювання у сфері надрокористування.

Ознакою здійснення адміністративних процедур у сфері захисту довкілля та природних ресурсів $€$, як правило, їх платний характер. Наприклад, встановлено, що за видачу спеціального дозволу на користування надрами за результатами продажу на аукціоні встановлено, що розмір плати за надання спеціальних дозволів на користування надрами визначається за результатами проведення аукціону [4]. Початкова ціна продажу дозволу на аукціоні розраховується спеціально уповноваженим центральним органом виконавчої влади з геологічного вивчення та забезпечення раціонального використання надр, виходячи з вартості запасів і ресурсів корисних копалин родовищ або ділянок надр відповідно до Методики визначення початкової ціни продажу на аукціоні спеціального дозволу на користування надрами, затвердженої постановою Кабінету Міністрів України від 15.10.2004 № 1374 [5].

Крім того метою здійснення адміністративних процедур у сфрері захисту довкілля та природних ресурсів є забезпечення прав на використання об'єктів з обмеженим обігом з метою або без мети отримання прибутку. Природні ресурси, за свою сутністю, як правило, є об'єктами з обмеженим обігом. Зокрема, реалізація права на використання земельної ділянки відповідно до її цільового призначення вимагає від майбутнього землекористувача отримання дозволу на розроблення проекту відведення земельної ділянки, що передбачено Земельним кодексом України [6], Законом України «Про землеустрій» [7], Законом України «Про місцеве самоврядування в Україні» [8].

При цьому, як правило, виходячи з того, що суб'єктом звернення є господарююча особа, то необхідно говорити про переслідування мети отримання їм прибутку. Наприклад, видача ліцензії на провадження господарської діяльності, пов'язаної з промисловим виловом риби, крім внутрішніх водойм та річок, як адміністративна послуга, що надається Державним агентством рибного господарства України, на підставі нормативноправових положень, визначених у Законі України від 02.03.2015 № 222-VIII «Про ліцензування видів господарської діяльності» [9]; Постанові Кабінету Міністрів України від 05.08.2015 № 609 «Про затвердження переліку органів ліцензування та визнання такими, що втратили чинність, деяких постанов Кабінету Міністрів України» [10], Наказі Мінагрополітики від 31.05.2013 № 341, зареєстрованому в Мін'юсті 17.06.2013 за № 983/ 23512 «Про затвердження Ліцензійних умов провадження господарської діяльності, пов'язаної з промисловим виловом, крім внутрішніх водойм (ставків) господарств» [11] господарюючим суб'єктам 3 комерційною метою.

3 огляду на наведені особливості пропонуємо визначити поняття адміністративні процедури у сорері захисту довкілля та природних ресурсів як встановлений законодавством України порядок діяльності органів публічної адміністрації, результатом якої є прийняття адміністративного акта (довідки, дозволу, реєстрації, свідоцтва, рішення, ліцензії тощо), спрямованої на забезпечення природовикористання об'єкта відповідно до його цільового призначення з метою ведення господарської діяльності, реалізації інтересів суб'єктів звернення у створенні оптимальних умов життєдіяльності.

Очевидним є висновок про централізований підхід до визначення суб'єкта публічної адміністрації, що має право здійснювати адміністративні процедури у сфері захисту довкілля та природних ресурсів.

Адміністративні процедури у сфері захисту довкілля та природних ресурсів пропонується класифікувати за рядом критеріїв.

По-перше, за правовими наслідками, адміністративні процедури у сорері захисту довкілля та природних ресурсів поділяються на послуги:

а) правовстановлючого характеру (видача дозволу на проведення заходів із залученням тварин; видача рішень про надання земельних ділянок громадянам у власність, користування, тощо);

б) правопоновлюючого характеру (переоформлення ліцензії на постачання природного газу, газу (метану) вугільних родовищ за нерегульованим тарифом, переоформлення ліцензії на транспортування нафти магістральними трубопроводами тощо);

в) правоприпиняючого характеру (анулювання підтвердження законності вилучення водних біоресурсів із середовища їх існування та переробки продуктів лову за заявою суб'єкта господарювання, анулювання дозволу на виконання робіт підвищеної небезпеки та на експлуатацію (застосування) машин, механізмів, устаткування підвищеної небезпеки тощо);

ґ) змішані (видача рішення про затвердження технічної документації із землеустрою щодо встановлення меж зони дії особистого сервітуту та укладання договору особистого сервітуту під розміщення тимчасового об'єкта; видача рішення про надання дозволу на виготовлення технічної документації із землеустрою щодо встановлення меж земельної ділянки для подальшого надання її в користування; видача рішення щодо земельної ділянки комунальної власності, у разі припинення договору оренди земельної ділянки; видача рішення про надання згоди на подальше користування частинами земельних ділянок, на які поширюється право сервітуту під тимчасовими спорудами для здійснення підприємницької діяльності).

По-друге, за видом прийнятого адміністративного акту, адміністративні процедури у сфрері за- 
хисту довкілля та природних ресурсів поділяються на послуги з видачі:

а) посвідчувальні процедури (наприклад, видача посвідчення мисливця або його дублікату тощо):

б) процедури з отримання довідки (надання відомостей з Державного земельного кадастру у формі витягу з Державного земельного кадастру про землі в межах територій адміністративнотериторіальних одиниць; надання довідки з державної статистичної звітності про наявність земель та розподіл їх за власниками земель, землекористувачами, угіддями (за даними форми 6-зем));

в) дозвільні процедури (за наявності пенсійного посвідчення в суб'єкта звернення за послугою, що наведена в попередньому пункті; надання дозволу на припинення права на аліменти на дитину у зв'язку з придбанням нею права власності на нерухоме майно);

г) ліцензійні процедури (видача ліцензії на зберігання природного газу, газу (метану) вугільних родовищ в обсягах, що перевищують рівень, встановлений ліцензійними умовами або її переоформлення; видача ліцензії на провадження господарської діяльності з виробництва вибухових матеріалів промислового призначення);

ґ) процедури з отримання рішення (видача рішень міської ради щодо земельних ділянок комунальної власності, у разі розірвання договору оренди земельної ділянки або припинення права постійного користування нею; видача рішення міської ради про надання згоди на продаж земельної ділянки комунальної власності та проведення її експертної грошової оцінки);

д) процедури з отримання відводу (надання гірничого відводу на розробку родовищ корисних копалин загальнодержавного значення, будівництво і експлуатацію підземних споруд та інші цілі, не пов'язані з видобуванням корисних копалин; реєстрація гірничих відводів, які надані на розробку родовищ корисних копалин місцевого значення);

е) процедури з отримання експертного висновку (проведення обов'язкової, добровільної державної експертизи землевпорядної документації, а також вибіркової державної експертизи землевпорядної документації (у разі видачі негативного висновку).

По-третє, залежно від суб'єкта-споживача адміністративні процедури у сорері захисту довкілля та природних ресурсів поділяються:

а) громадяни України (видача посвідчення мисливця або його дублікату; видача щорічної контрольної картки обліку добутої дичини і порушень правил полювання або її дублікату);

б) суб'єкти господарювання (видача дозволу на використання земель і водойм, розташованих в санітарно-захисній зоні ядерної установки, об'єкта, призначеного для поводження з радіоак- тивними відходами, уранового об'єкта; видача ліцензії на переробку уранових руд; видача ліцензії на перевезення радіоактивних матеріалів; видача ліцензії на переробку, зберігання радіоактивних відходів; видача ліцензії на виробництво джерел іонізуючого випромінювання; видача дозволів на перевезення радіоактивних матеріалів та внесення до них змін тощо);

По-четверте, за змістом та обсягом процедурних дій адміністративні процедури у сфері захисту довкілля та природних ресурсів поділяються на:

а) основні послуги, що надаються за заявами (видача рішення про продаж земельних ділянок державної та комунальної власності);

б) супутні послуги, передбачені як окремі обов'язкові процедури під час здійснення адміністративних процедур у сфері захисту довкілля та природних ресурсів (видача рішення про затвердження технічної документації із землеустрою щодо встановлення меж зони дії особистого сервітуту для подальшого укладення укладання договору особистого сервітуту під розміщення тимчасового об'єкта; надання гірничого відводу на розробку родовищ корисних копалин загальнодержавного значення, будівництво і експлуатацію підземних споруд та інші цілі, не пов'язані з видобуванням корисних копалин; реєстрація гірничих відводів, які надані на розробку родовищ корисних копалин місцевого значення);

в) додаткові послуги (виправлення технічної помилки у відомостях Державного земельного кадастру, яка була допущена не з вини органу, що здійснює його ведення; пошук, перегляд, копіювання та роздрукування відомостей з Державного земельного кадастру про частини земельної ділянки, на які поширюється дія сервітуту, договору суборенди земельної ділянки; пошук, перегляд, копіювання та роздрукування відомостей з Державного земельного кадастру про координати поворотних точок меж об'єктів кадастру (за один аркуш формату A4 (до 30 точок меж об'єктів); пошук, перегляд, копіювання та роздрукування відомостей з Державного земельного кадастру про бонітування ґрунтів (за 1 дм2 плану масштабу 1:5000-1:10000 за межами населених пунктів)).

Висновки 3 цього дослідження. Отже, адміністративні процедури у сфері захисту довкілля та природних ресурсів можна класифікувати за різними критеріями: за правовими наслідками надання, за суб'єктом-споживачем, за видом прийнятого адміністративного акту, за змістом та обсягом процедурних дій.

Акцентовано увагу класифікацію як за видом прийнятого адміністративного акту, адміністративні процедури у сфері захисту довкілля та природних ресурсів поділяються на послуги з видачі:

а) посвідчувальні процедури (наприклад, видача посвідчення мисливця або його дублікату 
тощо);

б) процедури з отримання довідки (надання відомостей з Державного земельного кадастру у фрормі витягу з Державного земельного кадастру про землі в межах територій адміністративнотериторіальних одиниць; надання довідки з державної статистичної звітності про наявність земель та розподіл їх за власниками земель, землекористувачами, угіддями (за даними форми 6-зем));

в) дозвільні процедури (за наявності пенсійного посвідчення в суб'єкта звернення за послугою, що наведена в попередньому пункті; надання дозволу на припинення права на аліменти на дитину у зв'язку з придбанням нею права власності на нерухоме майно);

г) ліцензійні процедури (видача ліцензії на зберігання природного газу, газу (метану) вугільних родовищ в обсягах, що перевищують рівень, встановлений ліцензійними умовами або її переоформлення; видача ліцензії на провадження господарської діяльності з виробництва вибухових матеріалів промислового призначення); ґ) процедури з отримання рішення (видача рішень міської ради щодо земельних ділянок комунальної власності, у разі розірвання договору оренди земельної ділянки або припинення права постійного користування нею; видача рішення міської ради про надання згоди на продаж земельної ділянки комунальної власності та проведення іï експертної грошової оцінки);

д) процедури з отримання відводу (надання гірничого відводу на розробку родовищ корисних копалин загальнодержавного значення, будівництво і експлуатацію підземних споруд та інші цілі, не пов'язані з видобуванням корисних копалин; реєстрація гірничих відводів, які надані на розробку родовищ корисних копалин місцевого значення);

е) процедури з отримання експертного висновку (проведення обов'язкової, добровільної державної експертизи землевпорядної документації, а також вибіркової державної експертизи землевпорядної документації (у разі видачі негативного висновку).

\section{БІБЛІОГРАФІЧНИЙ СПИСОК:}

1. Долечек В. С. Надання управлінських послуг населенню органами виконавчої влади України: організаційно-правовий аспект : дис. ...кандидата наук з державного управління : 25.00.02. К., 2005. 206 с.

2. Адміністративне право України: Академічний курс: підруч. (для студ. юрид. спец. вищих навч. закл.) : в 2 т. / (Авер'янов В. Б., Андрійко О. Ф., Битяк Ю. П. та ін.); голов редкол. : Авер'янов В. Б.(голова) (та ін.)). К. : Юридична думка, 2004. Т. 2 : Особлива частина. 583 с

3. Адміністративна процедура та адміністративні послуги. Зарубіжний досвід і пропозиції для України / (авт.-упоряд. : В. П. Тимощук). К. : Факт, 2003. 496 с.

4. Про затвердження переліків платних адміністративних послуг, які надаються Міністерством екології та природних ресурсів і Державною службою геології та надр : Постанова Кабінету Міністрів України від 1 червня 2011 р. № 705. Офріційний вісник України. 2011. № 51. Ст. 2037.

5. Про затвердження Методики визначення початкової ціни продажу на аукціоні спеціального дозволу на право користування надрами : постанова Кабінету Міністрів України від 15.10.2004 № 1374. Офріційний вісник України. 2004. № 42. Ст. 2772.

6. Земельний кодекс України : Закон України від 25.10.2001 р. Відомості Верховної Ради України. 2002. № 3-4. Ст. 27.

7. Про землеустрій : Закон України від 22.05.2003 р. Відомості Верховної Ради України. 2003. № 36. Ст.282.

8. Про місцеве самоврядування в Україні : Закон України від 21.05.1997 р. Відомості Верховної Ради України. 1997. № 24. ст.170.

9. Про ліцензування видів господарської діяльності : Закон України від 02.03.2015р. Відомості Верховної Ради. 2015. № 23. Ст.158.

10. Про затвердження переліку органів ліцензування та визнання такими, що втратили чинність, деяких постанов Кабінету Міністрів України : Постанова Кабінету Міністрів України від 05.08.2015 № 609. Офріційний вісник України. 2015. № 68. Ст. 2232.

11. Про затвердження Ліцензійних умов провадження господарської діяльності, пов'язаної з промисловим виловом, крім внутрішніх водойм (ставків) господарств : Наказ Мінагрополітики від 31.05.2013 р. № 341. Oфpiційний вісник України. 2013. № 50. Ст. 1829.

\section{REFERENCES:}

1. Dolechek, V.S. (2005). Providing management services to the population by the executive authorities of Ukraine: organizational and legal aspect: dis. ... Candidate of Sciences in Public Administration: 25.00.02. Kyiv. (in Ukrainian).

2. Averyanov, V.B. e.d. (2004). Administrative law of Ukraine: Academic course: textbook. (for law students of higher education): in 2 volumes. Kyiv: Yuridichna dumka. T. 2: Osoblyva chast. (in Ukrainian).

3. Tymoschuk, V.P. (2003). Administrative procedure and administrative services. Foreign experience and proposals for Ukraine / (author:). Kyiv. (in Ukrainian).

4. On approval of the lists of paid administrative services provided by the Ministry of Ecology and Natural Resources and the State Service of Geology and Subsoil: Resolution of the Cabinet of Ministers of Ukraine of June 1, 2011 № 705. Official Gazette of Ukraine. 2011. № 51. 2037 (in Ukrainian). 
5. On approval of the Methodology for determining the initial sale price at auction of a special subsoil use permit: Resolution of the Cabinet of Ministers of Ukraine of 15.10.2004 № 1374. Official Gazette of Ukraine. 2004. №42. 2772 (in Ukrainian).

6. Land Code of Ukraine (2002): Law of Ukraine of October 25, 2001. Information of the Verkhovna Rada of Ukraine. № 3-4. St. 27. (in Ukrainian).

7. On land management (2003).: Law of Ukraine of May 22, 2003. Information of the Verkhovna Rada of Ukraine. № 36. P.282. (in Ukrainian).

8. On local self-government in Ukraine (1997): Law of Ukraine of 21.05.1997. Information of the Verkhovna Rada of Ukraine. № 24. p.170. (in Ukrainian).

9. On licensing of economic activities (2015): Law of Ukraine of March 2, 2015. Information of the Verkhovna Rada. № 23. Art.158. (in Ukrainian).

10. On approval of the list of licensing bodies and recognition as invalid of some resolutions of the Cabinet of Ministers of Ukraine (2015): Resolution of the Cabinet of Ministers of Ukraine dated 05.08.2015 № 609. Official Gazette of Ukraine. № 68. Art. 2232. (in Ukrainian).

11. On approval of the License conditions for economic activities related to industrial fishing, except for inland waters (ponds) of farms (2013): Order of the Ministry of Agrarian Policy of 31.05.2013 № 341. Official Gazette of Ukraine. № 50. Art. 1829. (in Ukrainian). 